1 Herbert Hochberg

Russell, Moore and Wittgenstein

The Revival of Realism

ISBN 3-937202-00-5

334 pp., Hardcover € 94,00

2 Heinrich Ganthaler

Das Recht auf Leben in der Medizin

Eine moralphilosophische Untersuchung

ISBN 3-937202-01-3

167 pp., Hardcover $€ 58,00$

3 Ludger Jansen

Tun und Können

Ein systematischer Kommentar zu Aristoteles' Theorie der Vermögen im neunten Buch der "Metaphysik"

ISBN 3-937202-02-1

302 pp., Hardcover $€ 70,00$

4 Manuel Bremer

Der Sinn des Lebens

Ein Beitrag zur Analytischen

Religionsphilosophie

ISBN 3-937202-03-X

134 pp., Hardcover $€ 58,00$

5 Georg Peter

Analytische Ästhetik

Eine Untersuchung zu Nelson Goodman und zur literarischen Parodie

ISBN 3-937202-04-8, 332 pp.

Hardcover $€ 94,00$

6 Wolfram Hinzen / Hans Rott

Belief and Meaning

Essays at the Interface

ISBN 3-937202-05-6

250 pp., Hardcover $€ 58,00$

7 Hans Günther Ruß

Empirisches Wissen und

Moralkonstruktion

Eine Untersuchung zur Möglichkeit von

Brückenprinzipien in der Natur- und Bioethik

ISBN 3-937202-06-4

208 pp., Hardcover $€ 58,00$
8 Rafael Hüntelmann

Existenz und Modalität

Eine Studie zur Analytischen Modalontologie ISBN 3-937202-07-2

189 pp., Hardcover € 58,00

9 Andreas Bächli / Klaus Petrus

Monism

ISBN 3-937202-19-6

340 pp., Hardcover $€ 70,00$

10 Maria Elisabeth Reicher

Referenz, Quantifikation und ontologische Festlegung

ISBN 3-937202-39-0

ca. 300 pp., Hardcover $€ 89,00$

11 Herbert Hochberg / Kevin Mulligan

Relations and Predicates

ISBN 3-937202-51-X

250 pp., Hardcover $€ 74,00$

12 L. Nathan Oaklander

C. D. Broad's Ontology of Mind

ISBN 3-937202-97-8

105 pp., Hardcover $€ 39,00$

13 Uwe Meixner

The Theory of Ontic Modalities

ISBN 3-938793-11-2

374 pages, Hardcover,€ 79,00

14 Donald W. Mertz

Realist Instance Ontology and its Logic

ISBN 3-938793-33-3

252 pp., Hardcover, EUR 79,00

15 N. Psarros / K. Schulte-Ostermann (Eds.)

Facets of Sociality

ISBN 3-938793-39-2

370 pp., Hardcover, EUR 98,00 


\section{Nicholas Rescher}

\section{Collected Paper. 14 Volumes}

Nicholas Rescher is University Professor of Philosophy at the University of Pittsburgh where he also served for many years as Director of the Center for Philosophy of Science. He is a former president of the Eastern Division of the American Philosophical Association, and has also served as President of the American Catholic Philosophical Association, the American Metaphysical Society, the American G. W. Leibniz Society, and the C. S. Peirce Society. An honorary member of Corpus Christi College, Oxford, he has been elected to membership in the European Academy of Arts and Sciences (Academia Europaea), the Institut International de Philosophie, and several other learned academies. Having held visiting lectureships at Oxford, Constance, Salamanca, Munich, and Marburg, Professor Rescher has received seven honorary degrees from universities on three continents (2006 at the University of Helsinki). Author of some hundred books ranging over many areas of philosophy, over a dozen of them translated into other languages, he was awarded the Alexander von Humboldt Prize for Humanistic Scholarship in 1984.

ontos verlag has published a series of collected papers of Nicholas Rescher in three parts with altogether fourteen volumes, each of which will contain roughly ten chapters/essays (some new and some previously published in scholarly journals). The fourteen volumes would cover the following range of topics:

Volumes I - XIV

STUDIES IN 20TH CENTURY PHILOSOPHY ISBN 3-937202-78-1 · 215 pp. Hardcover, EUR 75,00

\section{STUDIES IN PRAGMATISM}

ISBN 3-937202-79-X · 178 pp. Hardcover, EUR 69,00

STUDIES IN IDEALISM

ISBN 3-937202-80-3 · 191 pp. Hardcover, EUR 69,00

STUDIES IN PHILOSOPHICAL INQUIRY

ISBN 3-937202-81-1 · 206 pp. Hardcover, EUR 79,00

STUDIES IN COGNITIVE FINITUDE

ISBN 3-938793-00-7 . 118 pp. Hardcover, EUR 69,00

STUDIES IN SOCIAL PHILOSOPHY

ISBN 3-938793-01-5 . 195 pp. Hardcover, EUR 79,00

STUDIES IN PHILOSOPHICAL ANTHROPOLOGY

ISBN 3-938793-02-3 . 165 pp. Hardcover, EUR 79,00

\section{ontos verlag}

Frankfurt • Paris • Lancaster $\bullet$ New Brunswick

2006. 14 Volumes, Approx. 2630 pages.

Format $14,8 \times 21 \mathrm{~cm}$

Hardcover EUR 798,00

ISBN 10: 3-938793-25-2

Due October 2006

Please order free review copy from the publisher Order form on the next page

\section{STUDIES IN VALUE THEORY}

ISBN 3-938793-03-1 . 176 pp. Hardcover, EUR 79,00

STUDIES IN METAPHILOSOPHY

ISBN 3-938793-04-X . 221 pp. Hardcover, EUR 79,00

STUDIES IN THE HISTORY OF LOGIC

ISBN 3-938793-19-8 . 178 pp. Hardcover, EUR 69,00

STUDIES IN THE PHILOSOPHY OF SCIENCE

ISBN 3-938793-20-1 . 273 pp. Hardcover, EUR 79,00

STUDIES IN METAPHYSICAL OPTIMALISM

ISBN 3-938793-21-X . 96 pp. Hardcover, EUR 49,00

STUDIES IN LEIBNIZ'S COSMOLOGY

ISBN 3-938793-22-8 . 229 pp. Hardcover, EUR 69,00

STUDIES IN EPISTEMOLOGY

ISBN 3-938793-23-6 . 180 pp. Hardcover, EUR 69,00 